Daniel Newsted, PhD; Dougal Bale, BPhty; Maxine Armstrong, MSc, CASLPO; Michael M. Beyea, MD, PhD, FRCPC; Matthew T.W. Simpson, MD, MSc, CD, CCFP: Sudeep S. Gill, MD, MSc, FRCPC; Jason A. Beyea, MD, PhD, FRCSC

Division of Otolaryngology/ Head and Neck Surgery, Department of Surgery, Queen's University School of Medicine, Kingston,

(Drs. Newsted and Jason

A. Beyea); Physiotherapy Outpatient Services, Providence Care Hospital, West Kingston (Mr. Bale); Quinte Hearing Centre, Belleville/Picton (Ms. Armstrong); Division of Emergency Medicine, Department of Medicine, McMaster University, Hamilton, and Department of Critical Care, William Osler Health System, Brampton (Dr. Michael M. Beyea); Department of Family Medicine, Queen's University School of Medicine, Kingston (Dr. Simpson); Division of Geriatric Medicine, Department of Medicine, Queen's University School of Medicine, Kingston (Dr. Gill); ICES Queen's, Queen's University, Kingston (Drs. Gill and Jason A. Beyea), Ontario, Canada

_tjason.beyea@queensu.ca

Dr. J.A. Beyea discloses that he has a proprietary interest in Kingston Ear Institute Inc. which is a multidisciplinary clinic that provides diagnostic and therapeutic services for hearing balance, and vestibular loss. Ms. Armstrong discloses a proprietary interest in Quinte Hearing Centre, which is a clinic that provides diagnostic and therapeutic services for hearing loss.

The other authors reported no potential conflict of interest relevant to this article.

doi: 10.12788/jfp.0332

\title{
How to identify balance disorders and reduce fall risk
}

\author{
A multifactorial risk assessment, correction of hearing \\ impairment, exercise, and an optimized home \\ environment can help prevent imbalance-related falls.
}

\section{PRACTICE RECOMMENDATIONS}

> Utilize a falls-prevention program for older patients that focuses on balance and functional exercises. (A)

> Perform a multifactorial assessment of the risk offalls in older patients that includes optimizing medications, managing comorbidities, and addressing environmental hazards. B

> Use a systems-based approach to presentations of imbalance to direct your clinical judgment and highlight the need for referral to specialists for management and rehabilitation. (c)

Strength of recommendation (SOR)

A Good-quality patient-oriented evidence

B Inconsistent or limited-quality patient-oriented evidence

C Consensus, usual practice, opinion, disease-oriented evidence, case series

\section{CASE}

Mr. J, a 75-year-old man, presents to your family practice reporting that he feels increasingly unsteady and slow while walking. He fell twice last year, without resulting injury. He now worries about tripping while walking around the house and relies on his spouse to run errands.

Clearly, Mr. J is experiencing a problem with balance. What management approach should you undertake to prevent him from falling?

$\mathrm{B}$ alance disorders are common in older people and drastically hinder quality of life. ${ }^{1-4}$ Patients often describe imbalance as vague symptoms: dizziness, unsteadiness, faintness, spinning sensations. ${ }^{5,6}$ Importantly, balance disorders disrupt normal gait and contribute to falls that are a major cause of disability and morbidity in older people. Almost $30 \%$ of people older than 65 years report 1 or more falls annually. ${ }^{7}$ Factors that increase the risk of falls include impaired mobility, previously reported falls, reduced psychological functioning, chronic medical conditions, and polypharmacy. ${ }^{7,8}$

The cause of any single case of imbalance is often multifactorial, resulting from dysfunction of multiple body systems (TABLE 1 ${ }^{7-56}$ ); in our clinical experience, most patients with imbalance and who are at risk of falls do not have a detectable deficit of the vestibular system. These alterations in function arise in 3 key systems-vision, proprioception, and vestibular function-which signal to, and are incorporated by, the cerebellum to mediate balance. Cognitive and neurologic decline are also factors in imbalance.

Considering that $20 \%$ of falls result in serious injury in older populations, it is important to identify balance disorders and implement preventive strategies to mitigate harmful consequences of falls on patients' health and independence. ${ }^{7,57} \mathrm{In}$ this article, we answer the question that the case presentation raises about the proper management approach to imbalance 


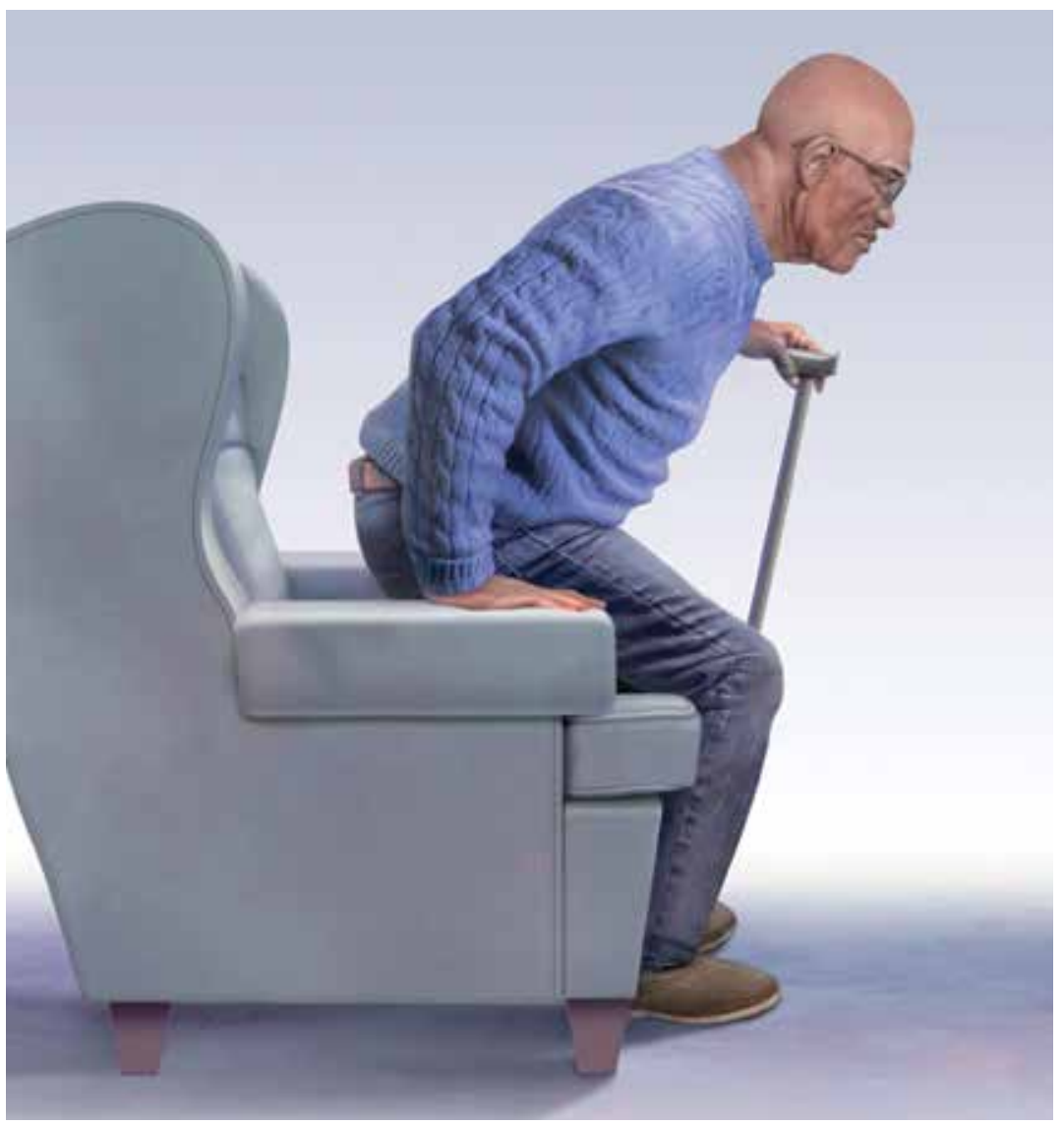

\section{Almost $30 \%$ of people older than 65 years report 1 or more falls annually.}

in family practice, including assessment of risk and rehabilitation strategies to reduce the risk of falls. Our insights and recommendations are based on our clinical experience and a review of the medical literature from the past 40 years.

\section{CASE D}

Mr. J has a history of hypertension, agerelated hearing loss, and osteoarthritis of the knees; he has not had surgery for the arthritis. His medications are antihypertensives and extra-strength acetaminophen for knee pain.

\section{Making the diagnosis of a balance disorder History}

I A thorough clinical history, often including a collateral history from caregivers, narrows the differential diagnosis. Information regarding onset, duration, timing, character, and previous episodes of imbalance is essential. Symptoms of imbalance are often challenging for the patient to describe: They might use terms such as vertigo or dizziness, when, in fact, on further questioning, they are describing balance difficulties. Inquiry into

(1) their use of assistive walking devices and

(2) development or exacerbation of neuro- logic, musculoskeletal, auditory, visual, and mood symptoms is necessary. Note the current level of their mobility, episodes of pain or fatigue, previous falls and associated injuries, fear of falling, balance confidence, and sensations that precede falls..$^{58}$

I The medical and surgical histories are key pieces of information. The history of smoking, alcohol habits, and substance use is relevant.

I A robust medication history is essential to evaluate a patient's risk of falling. Polypharmacy-typically, defined as taking 4 or more medications-has been repeatedly associated with a heightened risk of falls..$^{53,59-61}$ Moreover, a dose-dependent association between polypharmacy and hospitalization following falls has been identified, and demonstrates that taking 10 or more medications greatly increases the risk of hospitalization. ${ }^{59}$ Studies of polypharmacy cement the importance of inquiring about medication use when assessing imbalance, particularly in older patients.

\section{Physical examination}

A focused and detailed physical examination provides insight into systems that should be investigated:

- Obtain vital signs, including orthostatic vitals to test for orthostatic hypoten- 
TABLE 1

Symptoms and causes of imbalance, with potential next steps $s^{7-56}$

\begin{tabular}{|c|c|c|c|}
\hline System & $\begin{array}{l}\text { Signs and symptoms and clues } \\
\text { in the history }\end{array}$ & Causes & $\begin{array}{l}\text { Referral and other } \\
\text { next steps }\end{array}$ \\
\hline \multirow{4}{*}{ Peripheral } & $\begin{array}{l}\text { Impaired proprioception } \\
\text { Muscle atrophy } \\
\text { Paresthesia }\end{array}$ & Diabetic neuropathy & $\begin{array}{l}\text { Diabetes care team } \\
\text { or Endocrinology }\end{array}$ \\
\hline & $\begin{array}{l}\text { Ataxic gait } \\
\text { Confusion } \\
\text { Ophthalmoplegia } \\
\text { History of alcohol abuse, anorexia } \\
\text { nervosa, or bariatric surgery }\end{array}$ & Thiamine deficiency & Neurology \\
\hline & Sensorimotor polyneuropathy & $\begin{array}{l}\text { Autoimmune disease (Guillain-Barré } \\
\text { syndrome, systemic lupus erythematosus) } \\
\text { Malignancy (multiple myeloma, } \\
\text { paraneoplastic disease) } \\
\text { Organ dysfunction (hypothyroidism, } \\
\text { renal failure) }\end{array}$ & $\begin{array}{l}\text { Endocrinology, } \\
\text { Hematology, Neurology, } \\
\text { or Rheumatology }\end{array}$ \\
\hline & $\begin{array}{l}\text { Hearing loss } \\
\text { Tinnitus } \\
\text { Vertigo }\end{array}$ & $\begin{array}{l}\text { Benign paroxysmal positional vertigo } \\
\text { Labyrinthitis } \\
\text { Meniere disease } \\
\text { Presbycusis } \\
\text { Vestibular neuronitis }\end{array}$ & $\begin{array}{l}\text { Otolaryngology-head } \\
\text { and neck surgery } \\
\text { Vestibular physiotherapy }\end{array}$ \\
\hline \multirow{8}{*}{$\begin{array}{l}\text { Central } \\
\text { nervous system }\end{array}$} & $\begin{array}{l}\text { Acute ataxia } \\
\text { Hypertension } \\
\text { Neurologic symptoms } \\
\text { History of vascular disease }\end{array}$ & Stroke & $\begin{array}{l}\text { Neurology } \\
\text { Stroke protocol }\end{array}$ \\
\hline & $\begin{array}{l}\text { Fever } \\
\text { Headache } \\
\text { Neck stiffness }\end{array}$ & Meningitis & Emergency medicine \\
\hline & $\begin{array}{l}\text { Ataxic gait } \\
\text { Dysarthria } \\
\text { Slowly progressive headache }\end{array}$ & Posterior fossa tumors & Neurosurgery \\
\hline & $\begin{array}{l}\text { Gradual unilateral hearing loss } \\
\text { Tinnitus } \\
\text { Worsening imbalance }\end{array}$ & Vestibular schwannoma & $\begin{array}{l}\text { Otolaryngology-head } \\
\text { and neck surgery }\end{array}$ \\
\hline & $\begin{array}{l}\text { Episodic vertigo } \\
\text { Motion sensitivity } \\
\text { History of migraine }\end{array}$ & Vestibular migraines & Vestibular physiotherapy \\
\hline & $\begin{array}{l}\text { Altered gait } \\
\text { History of chronic alcohol abuse }\end{array}$ & Alcohol-related cerebellar degeneration & \multirow{3}{*}{ Neurology } \\
\hline & $\begin{array}{l}\text { Bradykinesia } \\
\text { Resting tremor } \\
\text { Rigidity } \\
\text { Slow, shuffling gait }\end{array}$ & Parkinsonian diseases & \\
\hline & $\begin{array}{l}\text { Multiple episodes of neurologic } \\
\text { dysfunction (ataxia and limb weakness) } \\
\text { separated in time and space }\end{array}$ & Multiple sclerosis & \\
\hline
\end{tabular}


TABLE 1

Symptoms and causes of imbalance, with potential next steps ${ }^{7-56}$ (cont'd)

\begin{tabular}{|c|c|c|c|}
\hline System & $\begin{array}{l}\text { Signs and symptoms and clues } \\
\text { in the history }\end{array}$ & Causes & $\begin{array}{l}\text { Referral and other } \\
\text { next steps }\end{array}$ \\
\hline \multirow{4}{*}{$\begin{array}{l}\text { Cognitive and } \\
\text { psychiatric }\end{array}$} & $\begin{array}{l}\text { Poor judgment } \\
\text { Slow progression of cognitive } \\
\text { impairment }\end{array}$ & Alzheimer disease & \multirow{3}{*}{ Geriatrics or Neurology } \\
\hline & $\begin{array}{l}\text { Dementia } \\
\text { Hallucinations } \\
\text { Parkinsonism }\end{array}$ & Dementia with Lewy bodies & \\
\hline & Focal motor or sensory deficits & Vascular dementia & \\
\hline & $\begin{array}{l}\text { Faintness } \\
\text { Dizziness } \\
\text { Fear of dying } \\
\text { Paraesthesia }\end{array}$ & $\begin{array}{l}\text { Anxiety } \\
\text { Depressive disorders }\end{array}$ & Psychiatry \\
\hline \multirow{4}{*}{ Biomechanical } & $\begin{array}{l}\text { Lower-limb joint pain } \\
\text { Decreased range of motion } \\
\text { Joint deformity }\end{array}$ & Lower limb osteoarthritis & \multirow{2}{*}{ Orthopedic surgery } \\
\hline & $\begin{array}{l}\text { Back pain that improves with flexion } \\
\text { Weakness or numbness in lower } \\
\text { extremities }\end{array}$ & Lumbar spinal stenosis & \\
\hline & $\begin{array}{l}\text { Kyphosis } \\
\text { Muscle weakness } \\
\text { Shortened stature }\end{array}$ & Osteoporosis & $\begin{array}{l}\text { Endocrinology, Orthopedic } \\
\text { surgery, or Rheumatology }\end{array}$ \\
\hline & $\begin{array}{l}\text { Chronic inflammation, nutritional } \\
\text { deficiency, or physical inactivity- } \\
\text { identified in the context of advanced } \\
\text { age } \\
\text { Loss of muscle mass } \\
\text { Reduced strength and functional } \\
\text { capacity }\end{array}$ & Sarcopenia & Geriatrics \\
\hline \multirow{3}{*}{ Cardiovascular } & $\begin{array}{l}\text { Dizziness } \\
\text { Dyspnea } \\
\text { Exertional chest pain }\end{array}$ & Coronary artery disease & \multirow{3}{*}{ Cardiology } \\
\hline & $\begin{array}{l}\text { Dyspnea } \\
\text { Palpitations } \\
\text { Syncope }\end{array}$ & Arrhythmia (eg, atrial fibrillation) & \\
\hline & $\begin{array}{l}\text { Imbalance } \\
\text { Right-ventricle dysfunction }\end{array}$ & $\begin{array}{l}\text { Cor pulmonale } \\
\text { Pericardial tamponade } \\
\text { Pulmonary hypertension } \\
\text { Valvular disease }\end{array}$ & \\
\hline
\end{tabular}

$\operatorname{sion}^{62}$; keep in mind that symptoms of orthostatic dizziness can occur without orthostatic hypotension.

- Examine gait, which can distinguish between causes of imbalance (TABLE 2). ${ }^{21,40,63-70}$
- Perform a cardiac examination.

- Assess visual acuity and visual fields; test for nystagmus and identify any optic-nerve and retinal abnormalities.

- Evaluate lower-limb sensation, proprioception, and motor function. 
TABLE 1

Symptoms and causes of imbalance, with potential next steps ${ }^{7-56}$ (cont'd)

\begin{tabular}{|c|c|c|c|}
\hline System & $\begin{array}{l}\text { Signs and symptoms and clues } \\
\text { in the history }\end{array}$ & Causes & $\begin{array}{l}\text { Referral and other } \\
\text { next steps }\end{array}$ \\
\hline Ophthalmic & $\begin{array}{l}\text { Imbalance aggravated by dimly lit } \\
\text { rooms } \\
\text { Vision loss }\end{array}$ & $\begin{array}{l}\text { Cataracts } \\
\text { Glaucoma-causing conditions } \\
\text { Macular degeneration }\end{array}$ & Ophthalmology \\
\hline \multirow{6}{*}{$\begin{array}{l}\text { Various } \\
\text { systems } \\
\text { adversely } \\
\text { affected by } \\
\text { medications }\end{array}$} & $\begin{array}{l}\text { Associated adverse signs and symptoms } \\
\text { of antiepileptic medications }\end{array}$ & - & \multirow{6}{*}{$\begin{array}{l}\text { Medication review } \\
\text { and optimization }\end{array}$} \\
\hline & $\begin{array}{l}\text { Associated adverse signs and symptoms } \\
\text { of cardiovascular medications }\end{array}$ & $\begin{array}{l}\text { Antihypertensives } \\
\text { Beta-blockers } \\
\text { Class 1A antiarrhythmics } \\
\text { Digoxin } \\
\text { Diuretics } \\
\text { Peripheral vasodilators } \\
\end{array}$ & \\
\hline & $\begin{array}{l}\text { Associated adverse signs and symptoms } \\
\text { of diabetes medications }\end{array}$ & $\begin{array}{l}\text { Insulin } \\
\text { Thiazolidinediones }^{\mathrm{a}}\end{array}$ & \\
\hline & $\begin{array}{l}\text { Associated adverse signs and symptoms } \\
\text { of opioids }\end{array}$ & - & \\
\hline & $\begin{array}{l}\text { Associated adverse signs and symptoms } \\
\text { of psychotropic medications }\end{array}$ & $\begin{array}{l}\text { Antidepressants (selective serotonin- } \\
\text { reuptake inhibitors, tricyclics) } \\
\text { Antipsychotics } \\
\text { Benzodiazepines }\end{array}$ & \\
\hline & $\begin{array}{l}\text { Associated adverse signs and symptoms } \\
\text { of vestibulotoxic medications }\end{array}$ & $\begin{array}{l}\text { Aminoglycosides (amikacin, gentamicin, } \\
\text { tobramycin) } \\
\text { Platinum-based chemotherapy }\end{array}$ & \\
\hline
\end{tabular}

a Drugs in this class increase the risk of fracture from a fall.

- Evaluate suspected vestibular dysfunction, including dysfunction with positional testing (the Dix-Hallpike maneuver $\left.{ }^{71}\right)$. The patient is taken from sitting to supine while the head is rotated $45^{\circ}$ to the tested side by the examiner. As the patient moves into a supine position, the neck is extended $30^{\circ}$ off the table and held for at least 30 seconds. The maneuver is positive if torsional nystagmus is noted while the head is held rotated during neck extension. The maneuver is negative if the patient reports dizziness, vertigo, unsteadiness, or "pressure in the head." Torsional nystagmus must be present to confirm a diagnosis of benign paroxysmal positional vertigo.

- If you suspect a central nervous system cause of imbalance, assess the cranial nerves, coordination, strength, and, of course, balance.

\section{CASE}

Mr. J's physical examination showed normal vital signs without significant postural changes in blood pressure. Gait analysis revealed a slowed gait, with reduced range of motion in both knees over the entire gait cycle. Audiometry revealed symmetric moderate sensorineural hearing loss characteristic of presbycusis.

\section{Diagnostic investigations}

Consider focused investigations into imbalance based on the history and physical examination. We discourage overly broad testing and imaging; in primary care, cost and limited access to technology can bar robust investigations into causes of imbalance. However, identification of acute pathologies should prompt immediate referral to the emergency department. Furthermore, specific symptoms (TABLE $1^{7-56}$ ) should prompt referral to specialists for assessment. 
TABLE 2

Abnormal gait patterns and associated pathologies ${ }^{21,40,63-70}$

\begin{tabular}{|c|c|c|}
\hline Gait pattern & Description & Associated pathology \\
\hline Hemiplegic & $\begin{array}{l}\text { Unilateral } \\
\text { Adduction of the shoulder } \\
\text { Circumduction of the paretic side } \\
\text { Flexion of the elbow } \\
\text { Internal rotation and extension of the leg } \\
\text { Pronation of the wrist }\end{array}$ & $\begin{array}{l}\text { Stroke } \\
\text { Brain tumor } \\
\text { Subdural hematoma }\end{array}$ \\
\hline Diplegic & $\begin{array}{l}\text { Bilateral } \\
\text { Adduction of the knees } \\
\text { Ankles extended and internally rotated } \\
\text { Flexion of hips and knees } \\
\text { Toes drag during swing phase }\end{array}$ & Cerebral palsy \\
\hline Neuropathic & $\begin{array}{l}\text { Unilateral or bilateral } \\
\text { Distal lower extremity affected } \\
\text { Foot drop and toe drag } \\
\text { High stepping gait }\end{array}$ & $\begin{array}{l}\text { Guillain-Barré syndrome } \\
\text { Multiple sclerosis } \\
\text { Spinal-disc herniation }\end{array}$ \\
\hline Myopathic & $\begin{array}{l}\text { Hyperlordosis } \\
\text { Trunk shifts to weight-bearing leg } \\
\text { Pelvis tilts to non-weight-bearing side (Trendelenburg sign) } \\
\text { Waddling }\end{array}$ & $\begin{array}{l}\text { Hip dislocation } \\
\text { Muscular dystrophy } \\
\text { Proximal motor neuropathy }\end{array}$ \\
\hline Choreiform & $\begin{array}{l}\text { Hyperkinetic } \\
\text { Involuntary movements in upper and lower extremities } \\
\text { Oral or facial dyskinesia }\end{array}$ & Huntington disease \\
\hline Cerebellar ataxia & $\begin{array}{l}\text { Difficulty on tandem walk } \\
\text { Staggering movements } \\
\text { Truncal titubation } \\
\text { Wide stance }\end{array}$ & $\begin{array}{l}\text { Alcohol ingestion } \\
\text { Cerebellar stroke } \\
\text { Multiple sclerosis }\end{array}$ \\
\hline Sensory ataxia & $\begin{array}{l}\text { Deficits in proprioceptive input } \\
\text { Foot slams on the ground } \\
\text { More evident in the dark } \\
\text { Stomping gait }\end{array}$ & $\begin{array}{l}\text { Diabetic neuropathy } \\
\text { Vitamin } B_{12} \text { deficiency }\end{array}$ \\
\hline Parkinsonian & $\begin{array}{l}\text { Bradykinesia } \\
\text { Festination } \\
\text { Head and neck in forward stoop } \\
\text { Knee flexion } \\
\text { Reduced arm swing } \\
\text { Small, shuffling steps forward } \\
\text { Start-and-turn hesitation } \\
\text { Tremors }\end{array}$ & $\begin{array}{l}\text { Atypical parkinsonism } \\
\text { Parkinson disease }\end{array}$ \\
\hline
\end{tabular}

In the emergency department and academic hospitals, key investigations can identify causes of imbalance:

- Electrocardiography and Holter moni- toring test for cardiac arrhythmias.

- Echocardiography identifies structural abnormalities.

- Radiography and computed tomogra- 


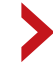

In our

experience, most patients with imbalance and who are at risk of falls do not have a detectable deficit of the vestibular system. phy are useful for detecting musculoskeletal abnormalities.

- Bone densitometry can identify osteoporosis.

- Head and spinal cord magnetic resonance imaging can be used to identify lesions of the central nervous system.

- Computed tomographic angiography of the head and neck is useful for identifying stroke, cerebral atrophy, and stenotic lesions of the carotid and vertebral arteries.

- Nerve conduction studies and levels of serum vitamin $\mathrm{B}_{12}$, hemoglobin $\mathrm{AlC}$, thyroid-stimulating hormone, and random cortisol can uncover causes of peripheral neuropathy.

- Bedside cognitive screening tests can be used to measure cognitive decline. ${ }^{72}$

- Suspicion of vestibular disease requires audiometry and vestibular testing, including videonystagmography, head impulse testing, and vestibular evoked myogenic potentials.

In many cases of imbalance, no specific underlying correctable cause is discovered.

\section{Management of imbalance \\ Pharmacotherapy}

Targeted pharmacotherapy can be utilized in select clinical scenarios:

- Medical treatment of peripheral neuropathy should target the underlying condition.

- Cognitive behavioral therapy and antidepressants are useful for treating anxiety and depressive disorders. ${ }^{73}$

- Musculoskeletal pain can be managed with acetaminophen and topical nonsteroidal anti-inflammatory drugs (NSAIDs), using a short course of an oral NSAID when needed. ${ }^{74}$

- Cardiovascular disease management might include any of several classes of pharmacotherapy, including antiplatelet and lipid-lowering medications, antiarrhythmic drugs, and antihypertensive agents.

- Acute episodes of vertigo due to vestibular neuritis or labyrinthitis can be managed with an antiemetic. ${ }^{46}$

\section{Surgical treatment}

Surgery is infrequently considered for patients with imbalance. Examples of indications include microsurgical resection of vestibular schwannoma, resection of central nervous system tumors, lens replacement surgery for cataract, surgical management of severe spinal fracture, and hip or knee arthroplasty in select patients.

\section{Tools for assessing}

the risk of falls

Scoring systems called falls risk assessment tools, or FRAT, have been developed to gauge a patient's risk of falling. The various FRATs differ in specificity and sensitivity for predicting the risk of falls, and are typically designed for specific clinical environments, such as hospital inpatient care or long-term care facilities. Specifically, FRATs attempt to classify risk using sets of risk factors known to be associated with falls.

Research abounds into the validity of commonly used FRATs across institutions, patient populations, and clinical environments:

I The Johns Hopkins FRAT ${ }^{\mathrm{a}}$ determines risk using metrics such as age, fall history, incontinence, cognition, mobility, and medications $^{75}$; it is predominantly used for assessment in hospital inpatient units. This tool has been validated repeatedly. ${ }^{76,77}$

I Peninsula Health FRAT $^{\mathrm{b}}$ stratifies patients in subacute and residential aged-care settings, based on risk factors that include recent falls, medications, psychological status, and cognition. ${ }^{78}$

I FRAT-up ${ }^{c}$ is a web-based tool that generates falls risk using risk factors that users input. This tool has been studied in the context of patients older than 65 years living in the community. ${ }^{79}$

Although FRATs are reasonably useful for predicting falls, their utility varies by patient population and clinical context. Moreover, it has been suggested that FRATs neglect

\footnotetext{
${ }^{\mathrm{a}}$ www.hopkinsmedicine.org/institute_nursing/models tools/jhfrat_acute\%20care\%20original_6_22_17.pdf

${ }^{\mathrm{b}}$ https://content.health.vic.gov.au/sites/default/files/ migrated/files/collections/policies-and-guidelines/b/ b2b_la_frat_pdf.pdf

${ }^{\mathrm{c}}$ www.ncbi.nlm.nih.gov/pmc/articles/PMC4376110/ figure/figure14/?report=objectonly
} 
environmental and personal factors when assessing risk by focusing primarily on bodily factors. ${ }^{80}$ Implementing a FRAT requires extensive consideration of the target population and should be accompanied by clinical judgment that is grounded in an individual patient's circumstances. ${ }^{81}$

\section{Preventing falls in primary care}

An approach to preventing falls includes the development of individualized programs that account for frailty, a syndrome of physiologic decline associated with aging. Because frailty leads to diminished balance and mobility, a patient's frailty index-determined using the 5 frailty phenotype criteria (exhaustion, weight loss, low physical activity, weakness, slowness ${ }^{82}$ or the Canadian Study of Health and Aging Clinical Frailty Scale ${ }^{83}$-is a useful tool for predicting falls risk and readmission for falls following trauma-related injury. Prevention of falls in communities is critical for reducing mortality and allowing older people to maintain their independence and quality of life.

I Exercise. In some areas, exercise and falls prevention programs are accessible to seniors. ${ }^{84}$ Community exercise programs that focus on balance retraining and muscle strengthening can reduce the risk of falls. ${ }^{73,85}$ The Choosing Wisely initiative of the ABIM [American Board of Internal Medicine] Foundation recommends that exercise programs be designed around an accurate functional baseline of the patient to avoid underdosed strength training. ${ }^{54}$

Multifactorial risk assessment in high-risk patients can reduce the rate of falls. Such an assessment includes examination of orthostatic blood pressure, vision and hearing, bone health, gait, activities of daily living, cognition, and environmental hazards, and enables provision of necessary interventions. ${ }^{73,86}$ Hearing amplification, specifically, correlates with enhanced postural control, slowed cognitive decline, and a reduced likelihood of falls. ${ }^{87-93}$ The mechanism behind improved balance performance might be reduced cognitive load through supporting a patient's listening needs. ${ }^{88-90}$

I Pharmacotherapy. Optimizing medications and performing a complete medication review before prescribing new medications is highly recommended to avoid unnecessary polypharmacy ${ }^{7,8,18,53-56}$ (TABLE $1^{7-56}$ ).

I Management of comorbidities associated with a higher risk of falls, including arthritis, cancer, stroke, diabetes, depression, kidney disease, chronic obstructive pulmonary disease, cognitive impairment, hypertension, and atrial fibrillation, is essential. ${ }^{94-96}$

I Home safety interventions, through occupational therapy, are important. These include removing unsafe mats and step-overs and installing nonslip strips on stairs, double-sided tape under mats, and handrails. ${ }^{73-97}$

I Screening for risk of falls. The Centers for Disease Control and Prevention recommends that (1) all patients older than 65 years and (2) any patient presenting with an acute fall undergo screening for their risk of falls ${ }^{98}$ When a patient is identified as at risk of falling, you can, when appropriate, assess modifiable risk factors and facilitate interventions. ${ }^{98}$ This strategy is supported by a 2018 statement from the US Preventive Services Task Force ${ }^{99}$ that recommends identifying high-risk patients who have:

- a history of falling

- a balance disturbance that causes a deficit of mobility or function

- poor performance on clinical tests, such as the 3-meter Timed Up and Go (TUG) assessment (www.cdc.gov/ steadi/pdf/TUG_test-print.pdf).

An increased risk of falls should prompt you to refer the patient to community programs and physiotherapy in accordance with the individual's personal goals ${ }^{99}$; a balance and vestibular physiotherapist is ideally positioned to accurately assess and manage patients at risk of falls. Specifically, the Task Force identified exercise programs and multifactorial interventions as being beneficial in preventing falls in high-risk older people. ${ }^{99}$

\section{Balance assessment and rehabilitation in specialty centers}

An individualized rehabilitation program aims to restore safe mobility by testing and addressing specific balance deficits, improving functional balance, and increasing balance confidence. Collaboration with colleagues from physiotherapy and occupational therapy aids in tailoring individualized programs.
In addition to visual, proprioception, and vestibular dysfunction, cognitive and neurologic decline are also factors in imbalance. 


\section{$>$}

Polypharmacy-
typically,
defined as
taking 4 or more
medications-
has been
repeatedly
associated with
a heightened
risk of falls.

Many tests are available to assess balance, determine the risk of falls, and guide rehabilitation:

- The timed 10-meter walk test $\mathrm{t}^{\mathrm{d}}$ and the TUG test are simple assessments that measure functional mobility; both have normalized values for the risk of falls. A TUG time of $\geq 12$ seconds suggests a high risk of falls.

- The 30-second chair stand e evaluates functional lower-extremity strength in older patients. The test can indicate if lower-extremity strength is contributing to a patient's imbalance.

- The modified clinical test of sensory interaction in balance ${ }^{\mathrm{f}}$ is a static balance test that measures the integrity of sensory inputs. The test can suggest if 1 or more sensory systems are compromised.

- The mini balance evaluation systems test $^{\mathrm{g}}$ is similar: It can differentiate balance deficits by underlying system and allows individualization of a rehabilitation program.

- The functional gait assessment ${ }^{\mathrm{h}}$ is a modification of the dynamic gait index that assesses postural stability during everyday dynamic activities, including tasks such as walking with head turns and pivots.

- The Berg Balance Scale continues to $^{\mathrm{i}}$ be used extensively to assess balance.

The mini balance evaluation systems test, functional gait index, and Berg Balance Scale all have normative age-graded values to predict fall risk.

\section{CASE}

Mr. J was referred for balance assessment and to a rehabilitation program. He underwent

d www.neuropt.org/docs/default-source/cpgs/coreoutcome-measures/core-measure-10-meter-walktest-(10mwt)_final.pdf?sfvrsn=c5585243_2\&sfvrsn $=$ c5585243_2

${ }^{\text {e }}$ www.cdc.gov/steadi/pdf/STEADI-Assessment30Sec-508.pdf

${ }^{\mathrm{f}}$ www.mdapp.co/mctsib-modified-clinical-test-ofsensory-interaction-in-balance-calculator-404/

${ }^{\mathrm{g}}$ www.sralab.org/sites/default/files/2017-07/MiniBEST_revised_final_3_8_13.pdf

${ }^{\mathrm{h}}$ www.neuropt.org/docs/default-source/cpgs/coreoutcome-measures/function-gait-assessment-pocketguide-proof9-(2).pdf?sfvrsn=b4f35043_0

${ }^{\mathrm{i}}$ www.ncbi.nlm.nih.gov/books/NBK574518/ balance physiotherapy, including multifactorial balance assessment, joined a community exercise program, was fitted with hearing aids, and had his home environment optimized by an occupational therapist. (See examples of "home safety interventions" under "Preventing falls in primary care" on page 27.)

13 months later. Mr. J says he feels stronger on his feet. His knee pain has eased, and he is more confident walking around his home. He continues to engage in exercise programs and is comfortable running errands with his spouse.

JFP

\section{CORRESPONDENCE}

Jason A. Beyea, MD, PhD, FRCSC, Division of OtolaryngologyHead and Neck Surgery, Queen's University, 144 Brock Street, Kingston, Ontario, Canada, K7L 5G2; jason.beyea@queensu.ca

\section{References}

1. Larocca NG. Impact of walking impairment in multiple sclerosis: perspectives of patients and care partners. Patient. 2011;4 189-201. doi: 10.2165/11591150-000000000-00000

2. Değer TB, Saraç ZF, Savaş ES, et al. The relationship of balance disorders with falling, the effect of health problems, and social life on postural balance in the elderly living in a district in Turkey. Geriatrics (Basel). 2019;4:37. doi: 10.3390/geriatrics4020037

3. Jönsson R, Sixt E, Landahl S, et al. Prevalence of dizziness and vertigo in an urban elderly population. J Vestib Res. 2004;14:47-52.

4. Sturnieks DL, St George R, Lord SR. Balance disorders in the elderly. Neurophysiol Clin. 2008;38:467-478. doi: 10.1016/ j.neucli.2008.09.001

5. Boult C, Murphy J, Sloane P, et al. The relation of dizziness to functional decline. J Am Geriatr Soc. 1991;39:858-861. doi: 10.1111/ j.1532-5415.1991.tb04451.x

6. Lin HW, Bhattacharyya N. Balance disorders in the elderly: epidemiology and functional impact. Laryngoscope. 2012;122: 1858-1861. doi: 10.1002/lary.23376

7. Jia H, Lubetkin EI, DeMichele K, et al. Prevalence, risk factors, and burden of disease for falls and balance or walking problems among older adults in the U.S. Prev Med. 2019;126:105737. doi: 10.1016/j.ypmed.2019.05.025

8. Al-Momani M, Al-Momani F, Alghadir AH, et al. Factors related to gait and balance deficits in older adults. Clin Interv Aging. 2016;11:1043-1049. doi: 10.2147/CIA.S112282

9. Agrawal Y, Ward BK, Minor LB. Vestibular dysfunction: prevalence, impact and need for targeted treatment. $J$ Vestib Res. 2013;23:113-117. doi: 10.3233/VES-130498

10. Altinsoy B, Erboy F, Tanriverdi H, et al. Syncope as a presentation of acute pulmonary embolism. Ther Clin Risk Manag. 2016;12:1023-1028. doi: 10.2147/TCRM.S105722

11. Belvederi Murri M, Triolo F, Coni A, et al. Instrumental assessment of balance and gait in depression: a systematic review. Psychiatry Res. 2020;284:112687. doi: 10.1016/j.psychres.2019.112687

12. Bhattacharyya N, Gubbels SP, Schwartz SR, et al. Clinical practice guideline: benign paroxysmal positional vertigo (update). Otolaryngol Head Neck Surg. 2017;156(suppl 3):S1-S47. doi: $10.1177 / 0194599816689667$

13. Bösner S, Schwarm S, Grevenrath P, et al. Prevalence, aetiologies and prognosis of the symptom dizziness in primary care - a systematic review. BMC Fam Pract. 2018;19:33. doi: 10.1186/ s12875-017-0695-0

14. Brouwer MC, Tunkel AR, van de Beek D. Epidemiology, diagnosis, and antimicrobial treatment of acute bacterial meningitis Clin Microbiol Rev. 2010;23:467-492. doi: 10.1128/CMR.00070-09

15. Chad DA. Lumbar spinal stenosis. Neurol Clin. 2007;25:407-418. doi: 10.1016/j.ncl.2007.01.003

16. Conrad BP, Shokat MS, Abbasi AZ, et al. Associations of selfreport measures with gait, range of motion and proprioception 
in patients with lumbar spinal stenosis. Gait Posture. 2013;38: 987-992. doi: 10.1016/j.gaitpost.2013.05.010

17. de Luna RA, Mihailovic A, Nguyen AM, et al. The association of glaucomatous visual field loss and balance. Transl Vis Sci Technol. 2017;6:8. doi: 10.1167/tvst.6.3.8

18. DiSogra RM. Common aminoglycosides and platinum-based ototoxic drugs: cochlear/vestibular side effects and incidence. Semin Hear. 2019;40:104-107. doi: 10.1055/s-0039-1684040

19. Ebersbach G, Moreau C, Gandor F, et al. Clinical syndromes: parkinsonian gait. Mov Disord. 2013;28:1552-1559. doi: 10.1002/ mds. 25675

20. Evans WJ. Skeletal muscle loss: cachexia, sarcopenia, and inactivity. Am J Clin Nutr. 2010;91:1123S-1127S. doi: 10.3945/ ajcn.2010.28608A

21. Filli L, Sutter T, Easthope CS, et al. Profiling walking dysfunction in multiple sclerosis: characterisation, classification and progression over time. Sci Rep. 2018;8:4984. doi: 10.1038/ s41598-018-22676-0

22. Fritz NE, Kegelmeyer DA, Kloos AD, et al. Motor performance differentiates individuals with Lewy body dementia, Parkinson's and Alzheimer's disease. Gait Posture. 2016;50:1-7. doi: 10.1016/ j.gaitpost.2016.08.009

23. Furman JM, Jacob RG. A clinical taxonomy of dizziness and anxiety in the otoneurological setting. J Anxiety Disord. 2001;15:9-26. doi: 10.1016/s0887-6185(00)00040-2

24. Furman JM, Marcus DA, Balaban CD. Vestibular migraine: clinical aspects and pathophysiology. Lancet Neurol. 2013;12 706-715. doi: 10.1016/S1474-4422(13)70107-8

25. Gerson LW, Jarjoura D, McCord G. Risk of imbalance in elderly people with impaired hearing or vision. Age Ageing. 1989;18: 31-34. doi: 10.1093/ageing/18.1.31

26. Goudakos JK, Markou KD, Franco-Vidal V, et al. Corticosteroids in the treatment of vestibular neuritis: a systematic review and meta-analysis. Otol Neurotol. 2010;31:183-189. doi: 10.1097/ MAO.0b013e3181ca843d

27. Green AD, Colón-Emeric CS, Bastian L, et al. Does this woman have osteoporosis? JAMA. 2004;292:2890-2900. doi: 10.1001/ jama.292.23.2890

28. Hallemans A, Ortibus E, Meire F, et al. Low vision affects dynamic stability of gait. Gait Posture. 2010;32:547-551. doi: 10.1016/ j.gaitpost.2010.07.018

29. Handelsman JA. Vestibulotoxicity: strategies for clinical diagnosis and rehabilitation. Int J Audiol. 2018;57(suppl 4):S99-S107. doi: 10.1080/14992027.2018.1468092

30. Head VA, Wakerley BR. Guillain-Barré syndrome in general practice: clinical features suggestive of early diagnosis. Br J Gen Pract. 2016;66:218-219. doi: 10.3399/bjgp16X684733

31. Helbostad JL, Vereijken B, Hesseberg K, et al. Altered vision destabilizes gait in older persons. Gait Posture. 2009;30:233-238. doi: 10.1016/j.gaitpost.2009.05.004

32. Hsu W-L, Chen C-Y, Tsauo J-Y, et al. Balance control in elderly people with osteoporosis. J Formos Med Assoc. 2014;113:334-339. doi: 10.1016/j.jfma.2014.02.006

33. Kim H-S, Yun DH, Yoo SD, et al. Balance control and knee osteoarthritis severity. Ann Rehabil Med. 2011;35:701-709. doi: 10.5535/arm.2011.35.5.701

34. Li L, Simonsick EM, Ferrucci L, et al. Hearing loss and gait speed among older adults in the United States. Gait Posture. 2013;38:2529.

35. McKeith IG, Boeve BF, Dickson DW, et al. Diagnosis and management of dementia with Lewy bodies: fourth consensus report of the DLB Consortium. Neurology. 2017;89:88-100. doi: 10.1212/ WNL.0000000000004058

36. Milner KA, Funk M, Richards S, et al. Gender differences in symptom presentation associated with coronary heart disease. Am J Cardiol. 1999;84:396-399. doi: 10.1016/ s0002-9149(99)00322-7

37. Paillard T, Noé F, Bru N, et al. The impact of time of day on the gait and balance control of Alzheimer's patients. Chronobiol Int 2016;33:161-168. doi: 10.3109/07420528.2015.1124885

38. Paldor I, Chen AS, Kaye AH. Growth rate of vestibular schwannoma. J Clin Neurosci. 2016;32:1-8. doi: 10.1016/j.jocn.2016.05.003

39. Picorelli AMA, Hatton AL, Gane EM, et al. Balance performance in older adults with hip osteoarthritis: a systematic review. Gait Posture. 2018;65:89-99. doi: 10.1016/j.gaitpost.2018.07.001

40. Raccagni C, Nonnekes J, Bloem BR, et al. Gait and postura disorders in parkinsonism: a clinical approach. J Neurol. 2020;267:3169-3176. doi: 10.1007/s00415-019-09382-1
41. Shanmugarajah PD, Hoggard N, Currie S, et al. Alcohol-related cerebellar degeneration: not all down to toxicity? Cerebellum Ataxias. 2016;3:17. doi: 10.1186/s40673-016-0055-1

2. Shih RY, Smirniotopoulos JG. Posterior fossa tumors in adult patients. Neuroimaging Clin N Am. 2016;26:493-510. doi: 10.1016/ j.nic.2016.06.003

43. Smith EE. Clinical presentations and epidemiology of vascular dementia. Clin Sci (Lond). 2017;131:1059-1068. doi: 10.1042/ CS20160607

44. Streur M, Ratcliffe SJ, Ball J, et al. Symptom clusters in adults with chronic atrial fibrillation. I Cardiovasc Nurs. 2017;32:296-303. doi: 10.1097/JCN.0000000000000344

45. Strupp M, Mandalà M, López-Escámez, JA. Peripheral vestibular disorders: an update. Curr Opin Neurol. 2019;32:165-173. doi: 10.1097/WCO.0000000000000649

46. Thompson TL, Amedee R. Vertigo: a review of common peripheral and central vestibular disorders. Ochsner J. 2009;9:20-26.

47. Timar B, Timar R, Gaiță L, et al. The impact of diabetic neuropathy on balance and on the risk of falls in patients with type 2 diabetes mellitus: a cross-sectional study. PLoS One. 2016;11:e0154654. doi: 10.1371/journal.pone.0154654

48. Walls R, Hockberger R, Gausche-Hill M. Peripheral nerve disorders. In: Rosen's Emergency Medicine: Concepts and Clinical Practice. 9th ed. Elsevier, Inc; 2018:1307-1320.

49. Watson JC, Dyck PJB. Peripheral neuropathy: a practical approach to diagnosis and symptom management. Mayo Clin Proc. 2015;90:940-951. doi: 10.1016/j.mayocp.2015.05.004

50. Whitfield KC, Bourassa MW, Adamolekun B, et al. Thiamine deficiency disorders: diagnosis, prevalence, and a roadmap for global control programs. Ann N Y Acad Sci. 2018;1430:3-43. doi: $10.1111 /$ nyas. 13919

51. Wu V, Sykes EA, Beyea MM, et al. Approach to Meniere disease management. Can Fam Physician. 2019;65:463-467.

52. Yew KS, Cheng EM. Diagnosis of acute stroke. Am Fam Physician 2015;91:528-536.

53. Seppala LJ, van de Glind EMM, Daams JG, et al; EUGMS Task and Finish Group on Fall-Risk-Increasing Drugs. Fall-riskincreasing drugs: a systematic review and meta-analysis: III Others. J Am Med Dir Assoc. 2018;19:372.e1-372.e8. doi: 10.1016/ j.jamda.2017.12.099

54. ABIM Foundation. Choosing wisely. Choosing Wisely website. 2021. Accessed November 11. 2021. www.choosingwisely.org/

55. Berlie HD, Garwood CL. Diabetes medications related to an in creased risk of falls and fall-related morbidity in the elderly. Ann Pharmacother. 2010;44:712-717. doi: 10.1345/aph.1M551

56. Hartikainen S, Lönnroos E, Louhivuori K. Medication as a risk factor for falls: critical systematic review. J Gerontol A Biol Sci Med Sci. 2007;62:1172-1181. doi: 10.1093/gerona/62.10.1172

57. Khanuja K, Joki J, Bachmann G, et al. Gait and balance in the aging population: Fall prevention using innovation and technology. Maturitas. 2018;110:51-56. doi: 10.1016/ j.maturitas.2018.01.021

58. Salzman B. Gait and balance disorders in older adults. Am Fam Physician. 2010;82:61-68.

59. Zaninotto P, Huang YT, Di Gessa G, et al. Polypharmacy is a risk factor for hospital admission due to a fall: evidence from the English Longitudinal Study of Ageing. BMC Public Health 2020;20:1804. doi: 10.1186/s12889-020-09920-x

60. Morin L, Calderon Larrañaga A, Welmer AK, et al. Polypharmacy and injurious falls in older adults: a nationwide nested casecontrol study. Clin Epidemiol. 2019;11:483-493. doi: 10.2147/ CLEP.S201614

61. Dhalwani NN, Fahami R, Sathanapally H, et al. Association between polypharmacy and falls in older adults: a longitudinal study from England. BMJ Open. 2017;7:e016358. doi: 10.1136/ bmjopen-2017-016358

62. Arnold AC, Raj SR. Orthostatic hypotension: a practical approach to investigation and management. Can J Cardiol. 2017;33 1725-1728. doi: 10.1016/j.cjca.2017.05.007

63. Alexander NB. Differential diagnosis of gait disorders in older adults. Clin Geriatr Med. 1996;12:689-703.

64. Baker JM. Gait disorders. Am J Med. 2018;131:602-607. doi: 10.1016/j.amjmed.2017.11.051

65. Cameron MH, Wagner JM. Gait abnormalities in multiple sclerosis: pathogenesis, evaluation, and advances in treatment. Curr Neurol Neurosci Rep. 2011;11:507-515. doi: 10.1007/s11910-011-0214-y

66. Chen C-L, Chen H-C, Tang SF-T, et al. Gait performance with compensatory adaptations in stroke patients with different de-
All patients older than 65 years and any patient presenting with an acute fall should undergo screening for their risk of falls. 
grees of motor recovery. Am J Phys Med Rehabil. 2003;82:925-935. doi: 10.1097/01.PHM.0000098040.13355.B5

67. Marsden J, Harris C. Cerebellar ataxia: pathophysiology and rehabilitation. Clin Rehabil. 2011;25:195-216. doi: $10.1177 / 0269215510382495$

68. Mirek E, Filip M, Chwała W, et al. Three-dimensional trunk and lower limbs characteristics during gait in patients with Huntington's disease. Front Neurosci. 2017;11:566. doi: 10.3389/ fnins.2017.00566

69. Paramanandam V, Lizarraga KJ, Soh D, et al. Unusual gait disorders: a phenomenological approach and classification. Expert Rev Neurother 2019:19:119-132. doi: 10.1080/ 14737175.2019.1562337

70. Sahyouni R, Goshtasbi K, Mahmoodi A, et al. Chronic subdural hematoma: a historical and clinical perspective. World Neurosurg. 2017;108:948-953. doi: 10.1016/j.wneu.2017.09.064

71. Talmud JD, Coffey R, Edemekong PF. Dix Hallpike maneuver StatPearls [Internet]. StatPearls Publishing Updated September 5, 2021. Accessed December 6, 2021. www.ncbi.nlm.nih.gov/ books/NBK459307/

72. Molnar FJ, Benjamin S, Hawkins SA, et al. One size does not fit all: choosing practical cognitive screening tools for your practice. J Am Geriatr Soc. 2020;68:2207-2213. doi: 10.1111/jgs.16713

73. Gillespie LD, Robertson MC, Gillespie WJ, et al. Interventions for preventing falls in older people living in the community. Cochrane Database Syst Rev. 2012:CD007146. doi: 10.1002/14651858.CD007146.pub3

74. Wongrakpanich S, Wongrakpanich A, Melhado K, Rangaswami J. A comprehensive review of non-steroidal anti-inflammatory drug use in the elderly. Aging Dis. 2018;9:143-150. doi: 10.14336/ AD.2017.0306

Exercise

programs

should be

designed around

an accurate

functional

baseline of the

patient to avoid

underdosed

strength

training.
75. Poe SS, Cvach M, Dawson PB, Straus $H$, Hill EE. The Johns Hopkins Fall Risk Assessment Tool: postimplementation evaluation. J Nurs Care Qual. 2007;22:293-298. doi: 10.1097/ 01.NCQ.0000290408.74027.39

76. Poe SS, Dawson PB, Cvach M, et al. The Johns Hopkins Fall Risk Assessment Tool: a study of reliability and validity. J Nurs Care Qual. 2018;33:10-19. doi: 10.1097/NCQ.0000000000000301

77. Klinkenberg WD, Potter P. Validity of the Johns Hopkins Fall Risk Assessment Tool for predicting falls on inpatient medicine services. J Nurs Care Qual. 2017;32:108-113. doi: 10.1097/ NCQ.0000000000000210

78. Stapleton C, Hough P, Oldmeadow L, et al. Four-item fall risk screening tool for subacute and residential aged care: the first step in fall prevention. Australas J Ageing. 2009;28:139-143. doi: 10.1111/j.1741-6612.2009.00375.x

79. Cattelani L, Palumbo P, Palmerini L, et al. FRAT-up, a Webbased fall-risk assessment tool for elderly people living in the community. I Med Internet Res. 2015;17:e41. doi: 10.2196/ jmir.4064

80. De Clercq H, Naudé A, Bornman J. Factors included in adult fall risk assessment tools (FRATs): a systematic review. Ageing Soc. 2020;41:2558-2582. doi: 10.1017/S0144686X2000046X

81. Yap G, Melder A. Accuracy of validated falls risk assessment tools and clinical judgement. Centre for Clinical Effectiveness, Monash Innovation and Quality. Monash Health. February 5 , 2020. Accessed November 11, 2021. https://monashhealth.org/ wp-content/uploads/2019/01/Rapid-Review_Falls-risk-toolsFINAL.pdf

82. Chittrakul J, Siviroj P, Sungkarat S, et al. Physical frailty and fall risk in community-dwelling older adults: a cross-sectional study. J Aging Res. 2020;2020:3964973. doi: $10.1155 / 2020 / 3964973$
83. Hatcher VH, Galet C, Lilienthal M, et al. Association of clinical frailty scores with hospital readmission for falls after index admission for trauma-related injury. JAMA Netw Open. 2019;2:e1912409. doi: 10.1001/jamanetworkopen.2019.12409

84. Exercise and fall prevention programs. Government of Ontario Ministry of Health. Updated April 9, 2019. Accessed November 11. 2021. www.ontario.ca/page/exercise-and-falls-preventionprograms

85. Sherrington C, Fairhall NJ, Wallbank GK, et al. Exercise for preventing falls in older people living in the community. Cochrane Database Syst Rev. 2019;1:CD012424. doi: 10.1002/14651858. CD012424.pub2

86. Hopewell S, Copsey B, Nicolson P, et al. Multifactorial interventions for preventing falls in older people living in the community: a systematic review and meta-analysis of 41 trials and almost 20000 participants. Br J Sports Med. 2020;54:1340-1350. doi: 10.1136/bjsports-2019-100732

87. Jafari Z, Kolb BE, Mohajerani MH. Age-related hearing loss and tinnitus, dementia risk, and auditory amplification outcomes. Ageing Res Rev. 2019;56:100963. doi: 10.1016/j.arr.2019.100963

88. Griffiths TD, Lad M, Kumar S, et al. How can hearing loss cause dementia? Neuron. 2020;108:401-412. doi: 10.1016/ j.neuron.2020.08.003

89. Martini A, Castiglione A, Bovo R, et al. Aging, cognitive load, dementia and hearing loss. Audiol Neurootol. 2014;19(suppl 1):2-5. doi: $10.1159 / 000371593$

90. Vitkovic J, Le C, Lee S-L, et al. The contribution of hearing and hearing loss to balance control. Audiol Neurootol. 2016;21: 195-202. doi: 10.1159/000445100

91. Maheu M, Behtani L, Nooristani M, et al. Vestibular function modulates the benefit of hearing aids in people with hearing loss during static postural control. Ear Hear. 2019;40:1418-1424. doi: 10.1097/AUD.0000000000000720

92. Negahban H, Bavarsad Cheshmeh Ali M, Nassadj G. Effect of hearing aids on static balance function in elderly with hearing loss. Gait Posture. 2017;58:126-129. doi: 10.1016/ j.gaitpost.2017.07.112

93. Mahmoudi E, Basu T, Langa K, et al. Can hearing aids delay time to diagnosis of dementia, depression, or falls in older adults? J Am Geriatr Soc. 2019;67:2362-2369. doi: 10.1111/jgs.16109

94. Paliwal Y, Slattum PW, Ratliff SM. Chronic health conditions as a risk factor for falls among the community-dwelling US older adults: a zero-inflated regression modeling approach. Biomed Res Int. 2017;2017:5146378. doi: 10.1155/2017/5146378

95. Deandrea S, Lucenteforte E, Bravi F, et al. Risk factors for falls in community-dwelling older people: a systematic review and meta-analysis. Epidemiology. 2010;21:658-668. doi: 10.1097/ EDE.0b013e3181e89905

96. Ambrose AF, Paul G, Hausdorff JM. Risk factors for falls among older adults: a review of the literature. Maturitas. 2013;75:51-61. doi: 10.1016/j.maturitas.2013.02.009

97. Stevens M, Holman CD, Bennett N. Preventing falls in older people: impact of an intervention to reduce environmental hazards in the home. J Am Geriatr Soc. 2001;49:1442-1447. doi: 10.1046/j.1532-5415.2001.4911235.x

98. Clinical resources. Centers for Disease Control and Prevention STEADI-Older Adult Fall Prevention website. 2020. Accessed November 12, 2021. www.cdc.gov/steadi/materials.html

99. US Preventive Services Task Force; Grossman DC, Curry SJ, Owens DK, et al. Interventions to prevent falls in communitydwelling older adults: US Preventive Services Task Force recommendation statement. JAMA. 2018;319:1696-1704. doi: 10.1001/ jama.2018.3097 